\title{
DISCUSSION POINT
}

\section{ON THE INTERNATIONAL BIBLIOGRAPHY OF ETHNOLOGY}

\section{Karin Maria Rooleid}

The international bibliography of ethnology Internationale Volkskundliche Bibliographie has been issued periodically since 1919. The time frame of the bibliography is 82 years, from the year 1917 to 1998 . In total 44 volumes have been published, of those 12 volumes covering one year, and 32 covering more than one. Up to the present the bibliography has been edited and printed in Switzerland, Germany, Austria and the USA. On 15 August 2002 the editing started in Estonia.

The publication of the next volume of IFB has been under the responsibility of the Chair of Estonian and Comparative Folklore at the University of Tartu (Universität Tartu, Lehrstuhl für estnische und vergleichende Folklore, Dr. Ülo Valk, chairman) and the Department of Folkloristics of the Estonian Literary Museum (Estnisches Literaturmuseum, Abteilung für Folkloristik, Dr. Mare Kõiva, head of department, Tartu; Karin Maria Rooleid, editor, Tallinn).

Other institutions involved continuous in the project are the German Society of Ethnology (Deutsche Gesellschaft für Volkskunde (DGV), Dr. Silke Göttsch, chairman, Kiel) and the International Society of Ethnology and Folklore (Société Internationale d'Ethnologie et de Folklore (SIEF), Commission for Bibliography, Information and Documentation, Dr. Regina Bendix, chairman, Göttingen).

The publication is sponsored by the member of the Swiss Academy of Humanitarian and Social Sciences (Schweizerische Akademie der Geistes- und Sozialwissenschaften, Bern) Swiss Society of Ethnology (Schweizerische Gesellschaft für Volkskunde, Ernst J. Huber, archivist, Basel), by the Society of Ethnology in Vienna (Verein für Volkskunde in Wien) and the Austrian Museum of Ethnology (Österreichisches Museum für Volkskunde, Hermann F. Hummer, 
archivist, Wien), the Museum of European Cultures (Museum Europäischer Kulturen, Dr. Konrad Vanja, chairman, Berlin), and the Institute of Saxonian History and Folk Culture (Institut für Sächsische Geschichte und Volkskunde e. V. Dresden, Dr. Enno Bünz, chairman, Leipzig and Dr. Winfried Müller, chairman, Dresden).

The volume for the year 1999 will be printed by the printing office Dr. Rudolf Habelt GmbH (Dr. Rudolf Habelt GmbH Verlag, Dr. Susanne Biegert, editor, Bonn). At the same time the databank will be available over the Internet (Bremen Universität, database manager, Klaus-Peter Busche). Also are proposed to continue the conferences of the IFB work-groups (Kommission der SIEF, Arbeitsgruppe für die IVB), for discussing technical matters related to the bibliography.

Unfortunately, the full set of IFB is not available in the libraries of Estonia. Out of the number of 44 volumes there are obtainable only 31 volumes, and even those are divided in between Tartu (17 vol.) and Tallinn (14 vol.). In Tartu, there are available 12 volumes (19171931/1932, 1957/1958) in the Library of the Estonian National Museum, 3 volumes (1931/1932, 1937/1938, 1955/1956) in the Archival Library of the Estonian Literary Museum, 1 volume (1995) in the Tartu University Library, and 1 volume (1998) in the Chair of Estonian and Comparative Folklore at the University of Tartu. All the other volumes are available in Tallinn, i.e. 6 volumes (1925/19261927, 1973/1974-1979/1980) in the Academic Library of Estonia, 5 volumes $(1931 / 1932,1935 / 1936,1991 / 1992-1994)$ in the National Library of Estonia, and 10 volumes (1973/1974-1983/1984, 19951998) can be found in the Tallinn branch of the Folklore Department of the Estonian Literary Museum.

Therefore the material used in the current overview was gathered mostly from the articles of the previous editors of the bibliography, and printed publications related to this issue. In particular I would like to thank the most recent editor of bibliography Dr. Rainer Alsheimer for sending to Tallinn the indispensable copies, and 6 volumes of IFB (1973/1974-1983/1984). 


\section{The title of the publication:}

1917 (1919) - 1935/1936 (1941): Volkskundliche Bibliographie

1939/1941 (1949) - 1942/1947 (1950): Volkskundliche Bibliographie = International Folklore and Folklife Bibliography = Bibliographie Internationale des Arts et Traditions Populaires

1948/1949 (1954) - 1977/1978 (1981): Internationale Volkskundliche Bibliographie = International Folklore and Folklife Bibliography = Bibliographie Internationale des Arts et Traditions Populaires

1979/1980 (1985) - 1998 (2001): Internationale Volkskundliche Bibliographie = International Folklore Bibliography = Bibliographie Internationale d'Ethnologie (IVB / IFB / BIE).

\section{Print data}

The total of 44 volumes / 82 years of IFB have been released thus far. As the first volume 1917 (1919) consists approximately 1,100 non-numerated entries, and all the other 43 volumes 1918 (1920) 1998 (2001) consist 326,790 entries, thus the number of entries in total is 327,890 . The result from this gives the average of entries per volume 7,452 .

\section{Editors (Herausgeber, 6)}

Eduard Hoffmann-Krayer, Paul Geiger, Robert Wildhaber, Rolf Wilhelm Brednich, James R. Dow, Rainer Alsheimer:

Eduard Hoffmann-Krayer (6 vol. / 8 issues)

Paul Geiger (8 vol. / 15 issues)

Paul Geiger and Robert Wildhaber (2 vol. / 8 issues)

Robert Wildhaber (12 vol. / 25 issues)

Robert Wildhaber and Rolf Wilhelm Brednich (1 vol. / 2 issues)

Rolf Wilhelm Brednich (2 vol. / 4 issues)

Rolf Wilhelm Brednich and James R. Dow (1 vol. / 2 issues)

James R. Dow and Rolf Wilhelm Brednich (2 vol. / 4 issues)

Rainer Alsheimer (10 vol. / 14 issues) 


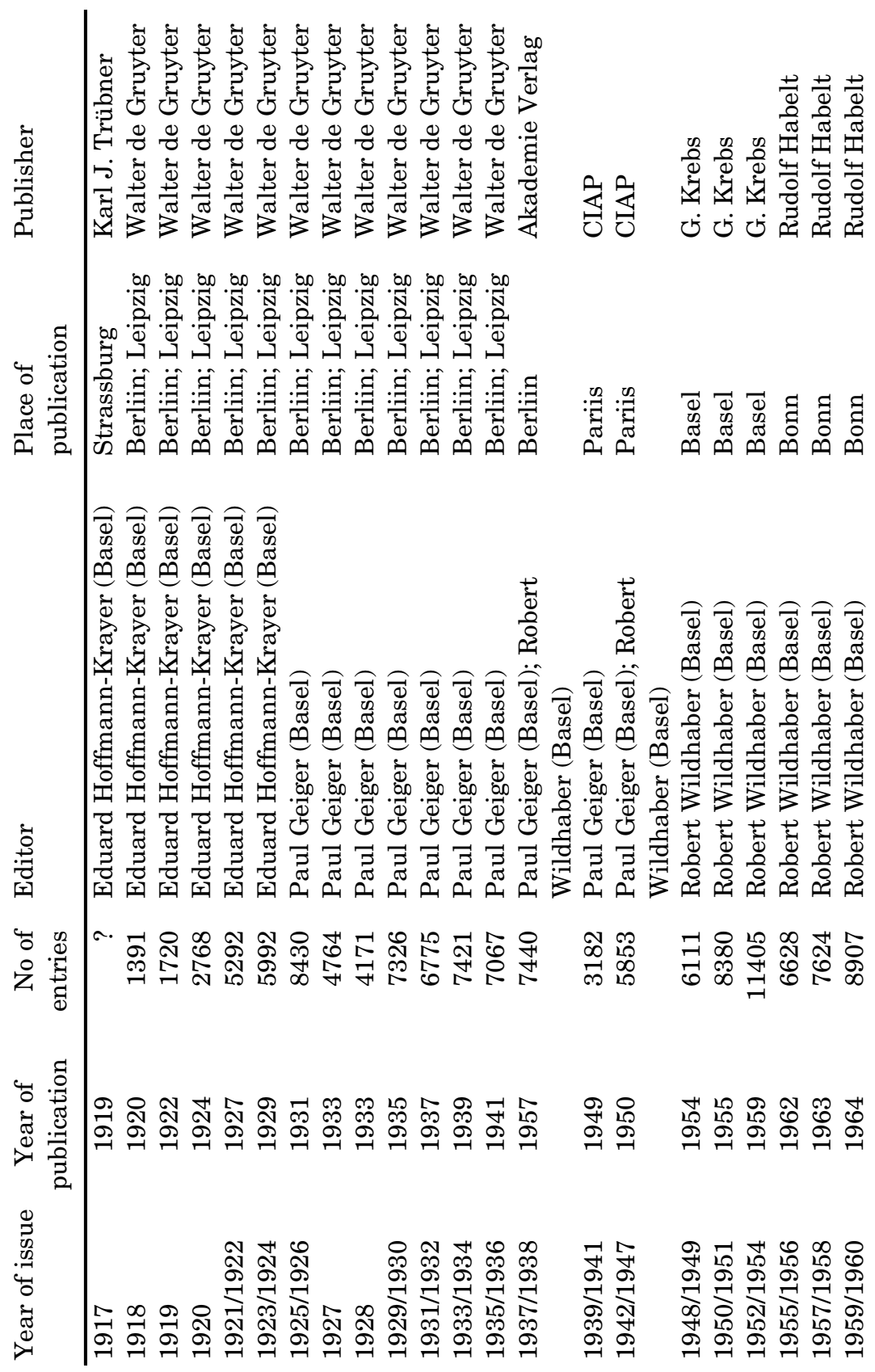




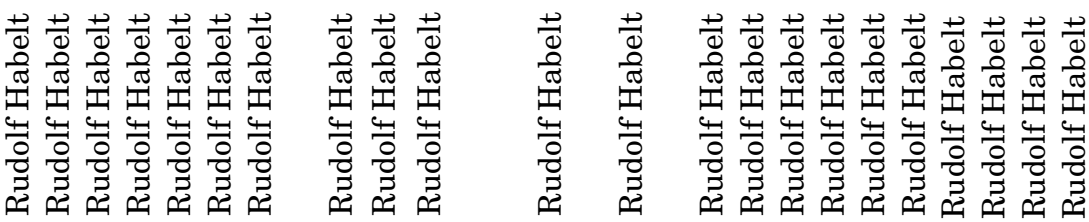

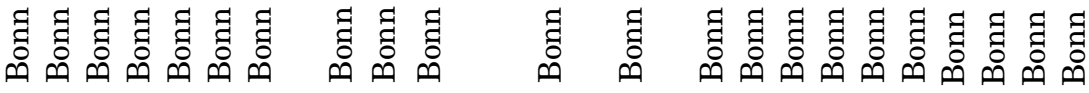

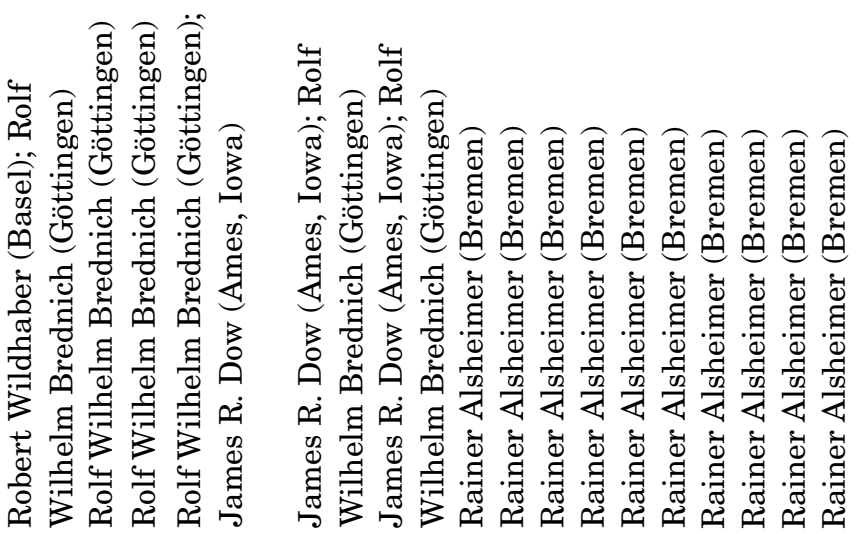

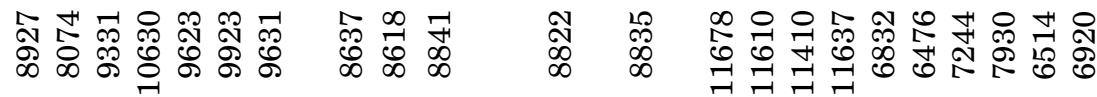

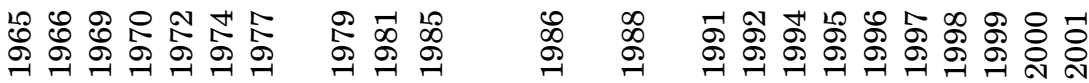

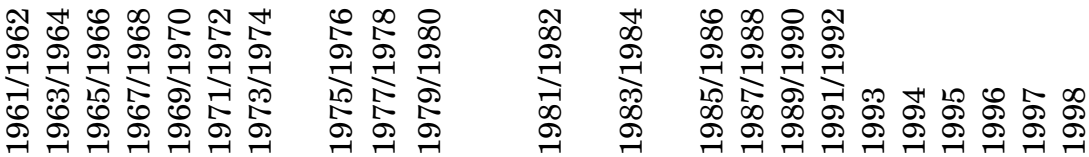




\section{Places of edition (Redaktionsorte, 4):}

Basel (28 vol.), Basel and Göttingen (1 vol.), Göttingen (2 vol.), Göttingen and Ames, Iowa (3 vol.), Bremen (10 vol.).

\section{Places of publication (Verlags- und Drucksorte, 6):}

Straßburg: Karl J. Trübner (1 vol., 1919), Berlin and Leipzig: Walter de Gruyter (12 vol., 1920-1941), Paris: CIAP (2 vol., 1949-1950), Berlin: Berliner Akademie-Verlag (1 vol., 1957), Basel: G. Krebs (3 vol., 1954-1959), and Bonn: Rudolf Habelt (25 vol., 1962-2001).

\section{Institutions responsible for issuing the bibliography (Auftragende Anstalten)}

1917 (1919) - 1998 (2001):Verband deutscher Vereine für Volkskunde / Deutsche Gesellschaft für Volkskunde (DGV, 1963-2001), Marburg etc.

1948/1949 (1954): CIAP, Bibliographie-Kommission = Commission nationale belge de folklore (1953), Namur.

1939/1941 (1949) - 1998 (2001): Conseil International de la Philosophie et des Sciences Humaines (CIPSH) der UNESCO; Société Internationale d'Ethnologie et de Folklore = International Society for Ethnology and Folklore = Internationale Gesellschaft für Ethnologie und Folklore (SIEF, 1964-2001), Amsterdam.

1977/1978 (1981) - 1983/1984 (1988): Union of Anthropological and Ethnological Sciences: Bibliographie-Kommission (IUAES, 1976), Ames, Iowa; Modern Language Association (MLA, 1981), New York.

1985/1986 (1991) - 1998 (2001): Universität Bremen, Arbeitsstelle Internationale Volkskundliche Bibliographie.

Institutions who granted the publication of the bibliography (Finanzielle Unterstützende Anstalten)

1917 (1919) - 1935/1936 (1941): Notgemeinschaft der Deutschen Wissenschaft etc.

1939/1941 (1949) - 1998 (2001): Conseil International de la Philosophie et des Sciences Humaines (CIPSH) der UNESCO; 
Deutsche Bundesregierung; Société Internationale d'Ethnologie et de Folklore (SIEF); Deutsche Gesellschaft für Volkskunde (DGV); Deutschen Forschungsgemeinschaft; Bonn, Bad Godesberg; Universität Bremen; Schweizerische Akademie der Geisteswissenschaften / Geistes- und Sozialwissenschaften, Bern; Schweizerische Gesellschaft für Volkskunde, Basel; Koninklijke Commissie voor Volkskunde, Brüssel etc.

Conferences of the work group for IFB (Tagungen der Arbeitsgruppe für die Internationale Volkskundliche Bibliographie)

01.-03.05.1990, Lilienthal bei Bremen (Germany)

19.-21.04.1991, Neusiedl am See (Austria)

30.04.-03.05.1992, Rheinfelden bei Basel (Switzerland)

01.-03.03.1993, Reinhausen bei Göttingen (Germany)

08.-10.09.1994, Petronell-Carnuntum; Kittsee (Austria)

24.-27.09.1996, Amsterdam (Netherlands)

7: 01.-04.09.1998, Trešt (Czech Republic)

\section{Changes of the editorial work in the last decade}

1979/1980 (1985) the first computer-generated issue was published; the data proccessing programs SINIX and XDOC (München) based on the operating system UNIX, and the layout-program LATEX were tested; plans were made to release the bibliography as a CDROM issue.

1989/1990 (1994) several new rubrics were added to the bibliography: 3. Ethnicity, Identity, Living Styles (Ethnizität, Identität, Lebensstile), 4. Age, Gender, Group (Alter, Geschlecht, Gruppen), 5. Economy, World of Work, Occupations (Ökonomie, Arbeitswelt, Berufe), and 24. Media (Medien).

1991/1992 (1995) the database management program BISMAS (Universität Oldenburg) was applied on the databank (Universität Bremen).

1993 (1996) was restored to publish the bibliography as one-volume issue. 
1995 (1998) the data proccessing program BISMAS (Universität Bremen, Klaus-Peter Busche) based on the operating system Windows95 was put to use in the databank of bibliography; the printed publication of IFB was generated by the layout-program LATEX (Roland Weibezahn, Achim); preparation work for the electronic publication of IFB was initiated (Meertens-Instituut, Amsterdam)

1996 (1999) for the first time the bibliographical contribution was submitted electronically on a floppy and as the attachment to an email (Nordiska Museet, Dr. Dag. M. Hermfeldt, Stockholm).

1997 (2000) Dr. Rainer Alsheimer announced his resignation from the editorial post after the release of the volume for the year 1998 (2001).

1998 (2001) IFB data base contained ca 88,000 entries; for the first time a contribution was downloaded through the Internet (database program MARC).

\section{Structure of IFB}

The editor of the first volume Dr. Eduard Hoffmann-Krayer created the main structure and arrangement of rubrics of IFB. According to this, each issue of IFB comprises in addition to the entries also the list of host publications, the indices of authors and subject words. Nevertheless, during the years the content of some rubrics and the arrangement of rubrics had been changed (e.g. Ethnology as a Science; Economy, World of Work, Occupations; Objects; Architecture, Building, Dwelling). Some rubrics have been merged. For example, the issue edited by Dr. Robert Wildhaber 1937/1938 (1957) comprised specific rubrics 13. Folk Medicine (Volksmedizin), 14. Folk Meteorology (Volksmeteorologie) and 22. Names (Namen), that occure in the present-day issue only as subrubrics 16.C. Health, Illness, the Body / Healing, 15.D. Popular Knowledge / Weather and Star Lore, and 22.F. Language / Names. The editor of the volume 1989/1990 (1994) Dr. Rainer Alsheimer added to the system completely new rubrics 3. Ethnicity, Identity, Living Styles, 4. Age, Gender, Group, and 24. Media. 
Likewise, in the course of the present editorial work the undersigned one had tried to comprehend the arrangement of the bibliography. For that reason the structure of IFB is now, in 2003, presented as follows:

\section{Rubrics (24)}

1.A.1. Ethnology as a Science / Bibliography and Sources / Bibliography

1.A.2. Ethnology as a Science / Bibliography and Sources / Sources

1.B.1. Ethnology as a Science / Reports on Ethnological Research / Directions of Teaching and Research, Scientific Societies

1.B.2. Ethnology as a Science / Reports on Ethnological Research / Congresses

1.B.3. Ethnology as a Science / Reports on Ethnological Research / Museums, Collections, Exhibitions

1.B.4. Ethnology as a Science / Reports on Ethnological Research / Personalia

1.B.5. Ethnology as a Science / Reports on Ethnological Research / Synoptic Reports on Countries and Peoples

1.C.1. Ethnology as a Science / History, Theory and Methods / History of Ethnology

1.C.2. Ethnology as a Science / History, Theory and Methods / Theory of Ethnology

1.C.3. Ethnology as a Science / History, Theory and Methods / Methods, Techniques, Aids

1.C.4. Ethnology as a Science / History, Theory and Methods / Ethnology and Neighbouring Disciplines

1.D.0. Ethnology as a Science / Processes of Culture

2.A.1. Regional Ethnology / General / Multiple Language Areas

2.A.2. Regional Ethnology / General / English Language Area

2.A.3. Regional Ethnology / General / French Language Area

2.A.4. Regional Ethnology / General / Italian Language Area

2.A.5. Regional Ethnology / General / Spanish, Catalan and Portuguese Language Area

2.A.6. Regional Ethnology / General / Other Romance Language Areas

2.A.7. Regional Ethnology / General / German Language Area

2.A.8. Regional Ethnology / General / Dutch and Friesian Language Area

2.A.9. Regional Ethnology / General / North Germanic Language Area

2.A.10. Regional Ethnology / General / Greek Language Area

2.A.11. Regional Ethnology / General / East Slavic Language Area

2.A.12. Regional Ethnology / General / West Slavic Language Area

2.A.13. Regional Ethnology / General / South Slavic Language Area

2.A.14. Regional Ethnology / General / Celtic Language Area 
2.A.15. Regional Ethnology / General / Other Indo-European Language Areas

2.A.16. Regional Ethnology / General / Finno-Ugric Language Area

2.A.17. Regional Ethnology / General / Other Language Areas

3.A.0. Ethnicity, Identity, Living Styles / General

3.B.0. Ethnicity, Identity, Living Styles / Stereotypes, Values, Norms

3.C.0. Ethnicity, Identity, Living Styles / Home Country, Nationality

3.D.0. Ethnicity, Identity, Living Styles / Minorities

3.E.0. Ethnicity, Identity, Living Styles / Migration

4.A.0. Age, Gender, Group / General

4.B.0. Age, Gender, Group / Women

4.C.0. Age, Gender, Group / Men

4.D.0. Age, Gender, Group / Marriage, Family

4.E.0. Age, Gender, Group / Children, Adolescence

4.F.0. Age, Gender, Group / Old People

4.G.0. Age, Gender, Group / Relationship, Adoption, Godparents

4.H.0. Age, Gender, Group / Neighbourhood

4.I.0. Age, Gender, Group / Other Social Groups

5.A.0. Economy, World of Work, Occupations / General

5.B.0. Economy, World of Work, Occupations / Gathering, Hunting, Fishing

5.C.0. Economy, World of Work, Occupations / Agriculture and Animal Husbandry, Forestry, Horticulture

5.D.0. Economy, World of Work, Occupations / Mining

5.E.0. Economy, World of Work, Occupations / Other Branches of the Economy

5.F.0. Economy, World of Work, Occupations / Handicrafts

5.G.0. Economy, World of Work, Occupations / Workers, Agricultural Workers, Factory Workers, Seasonal Workers

5.H.0. Economy, World of Work, Occupations / Traffic and Transport

5.I.0. Economy, World of Work, Occupations / Trade

5.J.0. Economy, World of Work, Occupations / Calendar, Reckoning of Time, Weights and Measures, Money

6.A.0. Folk Art, Popular Aesthetics / General

6.B.0. Folk Art, Popular Aesthetics / Imagery

6.C.0. Folk Art, Popular Aesthetics / Textiles

6.D.0. Folk Art, Popular Aesthetics / Wood

6.E.0. Folk Art, Popular Aesthetics / Ceramics

6.F.0. Folk Art, Popular Aesthetics / Stone

6.G.0. Folk Art, Popular Aesthetics / Metal

6.H.0. Folk Art, Popular Aesthetics / Glass

6.I.0. Folk Art, Popular Aesthetics / Other

7.A.0. Tokens, Symbols, Gesticulations, Gestures / General

7.B.0. Tokens, Symbols, Gesticulations, Gestures / Specific

8.A.0. Dress / General

8.B.0. Dress / Clothing Styles 
8.C.0. Dress / Individual Items of Dress

8.D.0. Dress / Accessories, Ornamentation

9.A.0. Food / General

9.B.0. Food / Techniques

9.C.0. Food / Eating habits

9.D.0. Food / Individual Food Items, Spices, Luxury Items

10.A.0. Settlement, Cultural Landscape / General

10.B.0. Settlement, Cultural Landscape / Rural Forms of Settlement

10.C.0. Settlement, Cultural Landscape / Urban Forms of Settlement

10.D.0. Settlement, Cultural Landscape / Cultural Landscape

10.E.0. Settlement, Cultural Landscape / Other

11.A.0. Architecture, Building, Dwelling / General

11.B.0. Architecture, Building, Dwelling / Dwelling House and Ways of Living

11.C.0. Architecture, Building, Dwelling / Farm and Work Buildings

11.D.0. Architecture, Building, Dwelling / Other Buildings: Churches, Chapels, Public Buildings

11.E.0. Architecture, Building, Dwelling / Cemeteries

11.F.0. Architecture, Building, Dwelling / Monuments

11.G.0. Architecture, Building, Dwelling / Other

12.A.0. Objects / General

12.B.0. Objects / Furniture and Household Equipment

12.C.0. Objects / Implements

12.D.0. Objects / Other Objects

13.A.0. Custom, Festival, Game, Spare Time / General

13.B.0. Custom, Festival, Game, Spare Time / Folk Festival, Folklore Movements

13.C.1. Custom, Festival, Game, Spare Time / Course of Life / General

13.C.2. Custom, Festival, Game, Spare Time / Course of Life / Birth, Baptism

13.C.3. Custom, Festival, Game, Spare Time / Course of Life / Love, Engagement, Marriage

13.C.4. Custom, Festival, Game, Spare Time / Course of Life / Death and Burial

13.D.1. Custom, Festival, Game, Spare Time / The Year's Round / General 13.D.2. Custom, Festival, Game, Spare Time / The Year's Round / Spring

13.D.3. Custom, Festival, Game, Spare Time / The Year's Round / Summer

13.D.4. Custom, Festival, Game, Spare Time / The Year's Round / Autumn

13.D.5. Custom, Festival, Game, Spare Time / The Year's Round / Winter

13.E.0. Custom, Festival, Game, Spare Time / Sport, Games

13.F.0. Custom, Festival, Game, Spare Time / Holidays, Travel, Tourism

13.G.0. Custom, Festival, Game, Spare Time / Professions, Occupations, Unions, Leagues

14.A.0. Religion, Piety / General 
14.B.0. Religion, Piety / Concepts and Phenomena

14.C.1. Religion, Piety / Institutions, Communities, Spiritual Movements / General

14.C.2. Religion, Piety / Institutions, Communities, Spiritual Movements / Missionary Activities

14.D.0. Religion, Piety / Personages

14.E.1. Religion, Piety / Rites, Cults / General

14.E.2. Religion, Piety / Rites, Cults / Worship of Saints, Pilgrimage

14.E.3. Religion, Piety / Rites, Cults / Times, Places

14.E.4. Religion, Piety / Rites, Cults / Objects

14.E.5. Religion, Piety / Rites, Cults / Consecrations, Prayers

14.E.6. Religion, Piety / Rites, Cults / Magic, Witchcraft

15.A.0. Popular Knowledge / General

15.B.0. Popular Knowledge / Plant Lore

15.C.0. Popular Knowledge / Animal Lore

15.D.0. Popular Knowledge / Weather and Star Lore

15.E.0. Popular Knowledge / Astrology, Fortune Telling, Divination, the Meaning of Dreams

15.F.0. Popular Knowledge / Folk Education, School

15.G.0. Popular Knowledge / Technology, Alchemy

15.H.0. Popular Knowledge / Other

16.A.0. Health, Illness, the Body / General

16.B.0. Health, Illness, the Body / Diseases

16.C.0. Health, Illness, the Body / Healing

16.D.0. Health, Illness, the Body / Hygiene

16.E.0. Health, Illness, the Body / Sexuality

16.F.0. Health, Illness, the Body / Body

16.G.0. Health, Illness, the Body / Other

17.A.0. Legal Ethnology / General

17.B.0. Legal Ethnology / Specific

18.A.0. Folklore / General

18.B.0. Folklore / Collections

18.C.0. Folklore / Context and Function

19.A.0. Songs / General

19.B.0. Songs / Collections

19.C.0. Songs / Context and Function

19.D.0. Songs / Ballads and Epic

19.E.0. Songs / Historical Songs, Political Songs, Broadside Ballads, Convivial Songs

19.F.0. Songs / Spiritual Songs

19.G.0. Songs / Love Songs, Lyrical Songs

19.H.0. Songs / Songs Associated with Customs

19.I.0. Songs / Occupational and Professional Songs

19.J.0. Songs / Children's Songs, Lullabies 
19.K.0. Songs / Pop Songs

19.L.0. Songs / Other Songs

20.A.0. Music, Dance / General

20.B.0. Music, Dance / Collections

20.C.0. Music, Dance / Context and Function

20.D.0. Music, Dance / Vocal Music

20.E.0. Music, Dance / Instrumental Music

20.F.0. Music, Dance / Musical Instruments

20.G.0. Music, Dance / Dance

21.A.0. Popular Prose and Reading Materials / General

21.B.0. Popular Prose and Reading Materials / Mixed Collections

21.C.0. Popular Prose and Reading Materials / Context and Function

21.D.0. Popular Prose and Reading Materials / Motifs and Themes

21.E.1. Popular Prose and Reading Materials / Narratives / Studies

21.E.2. Popular Prose and Reading Materials / Narratives / Collections

21.F.1. Popular Prose and Reading Materials / Fairytales / Studies

21.F.2. Popular Prose and Reading Materials / Fairytales / Collections

21.G.1. Popular Prose and Reading Materials / Legends / Studies

21.G.2. Popular Prose and Reading Materials / Legends / Collections

21.H.0. Popular Prose and Reading Materials / Fables

21.I.0. Popular Prose and Reading Materials / Comic Tales, Anecdotes, Jokes

21.J.0. Popular Prose and Reading Materials / Christian Legends

21.K.0. Popular Prose and Reading Materials / Popular Literature, Other Literature and Reading Materal

21.L.1. Popular Prose and Reading Materials / Minor Oral Genres / General

21.L.2. Popular Prose and Reading Materials / Minor Oral Genres / Collections

21.L.3. Popular Prose and Reading Materials / Minor Oral Genres / Proverbs, Sayings

21.L.4. Popular Prose and Reading Materials / Minor Oral Genres / Riddles

21.L.5. Popular Prose and Reading Materials / Minor Oral Genres / Other Minor Genres

22.A.0. Language / General

22.B.0. Language / Collections

22.C.0. Language / Context and Function

22.D.0. Language / The Speech of Ethnic and Regional Groups

22.E.0. Language / The Speech of Social Groups

22.F.0. Language / Names

23.A.0. Popular Drama, Circus, Entertainment / General

23.B.0. Popular Drama, Circus, Entertainment / Collections

23.C.0. Popular Drama, Circus, Entertainment / Context and Function 
23.D.0. Popular Drama, Circus, Entertainment/ Popular Drama, Epic Plays 23.E.0. Popular Drama, Circus, Entertainment / Circus

23.F.0. Popular Drama, Circus, Entertainment / Other

24.A.0. Media / General

24.B.0. Media / Press, Newspapers, Journals, Magazines

24.C.0. Media / Film, Television, Video

24.D.0. Media / Radio, Sound Carriers

24.E.0. Media / Telecommunication, Computers, Multimedia

\section{Language}

The main languages of the IFB are German, English and French. Therefore the titles registered in other languages should be translated into one of the main languages. As well the heading of chapter will be trilingual. But since most of the collaborators have been associated to the German-speaking culture area, i.e. to Germany, Austria and Switzerland, the subject index is presented in German language only.

\section{Collaborators (Mitarbeiter)}

Collaborators are competent professionals, working in a field of ethnology, folkloristics, or bibliography. The number of collaborators and volunteers has varied from volume to volume, ranging from 30 to 90 . Estonian material in IFB had been registered by Dr. Walter Anderson from 1917 to 1960, by Dr. Ants Viires from c. 1970 to 1991/1992 (1995), and by Karin Maria Rooleid (Ribenis) from 1991/ 1992 (1995) to 1998 (2001).

At the beginning of 2003 there was in all 70 collaborators of IFB, of these $26(37 \%)$ came from Germany and $14(20 \%)$ from Austria. As well the Nordic and Baltic countries, Central and Eastern Europe, Latin- and South-America have been represented. See Table on facing page, continued on next page. 


\begin{tabular}{|c|c|c|c|}
\hline No & Name & City & Country \\
\hline 1 & Rainer Alsheimer & Bremen & Germany \\
\hline 2 & $\begin{array}{l}\text { Heidrun Alzheimer- } \\
\text { Haller }\end{array}$ & Würzburg & Germany \\
\hline 3 & Krista Aru & Tartu & Estonia \\
\hline 4 & Klaus Beitl & Wien & Austria \\
\hline 5 & Zuzana Benusková & Bratislava & Slovakia \\
\hline 6 & Margit Berwing-Wittl & Burglengenfeld & Germany \\
\hline 7 & Andreas C. Bimmer & Warzenbach & Germany \\
\hline 8 & Martha Blache & Buenos Aires & Argentina \\
\hline 9 & Barbara Boock & Freiburg & Germany \\
\hline 10 & Gitta Böth & Hagen & Germany \\
\hline 11 & Rolf Wilhelm Brednich & Göttingen & Germany \\
\hline 12 & Michaela Brodl & Wien & Austria \\
\hline 13 & Wolfgang Brückner & Würzburg & Germany \\
\hline 14 & Klaus-Peter Busche & Bremen & Germany \\
\hline 15 & H. L. Cox & Bonn & Germany \\
\hline 16 & Manuel Dannemann & Santiago & Chile \\
\hline 17 & Brigitte Emmrich & Dresden & Germany \\
\hline 18 & Alexander Fenton & Edinburgh & Scotland \\
\hline 19 & Manfred Fischer & Salzburg & Austria \\
\hline 20 & Sigrid Fährmann & Göttingen & Germany \\
\hline 21 & Gerhard Gaigg & Ebensee & Austria \\
\hline 22 & Silke Göttsch & Kiel & Germany \\
\hline 23 & Wolfgang Gürtler & Eisenstadt & Austria \\
\hline 24 & Walter Hartinger & Passau & Germany \\
\hline 25 & Edgar Harvolk & München & Germany \\
\hline 26 & Elisabeth Haug & Freiburg & Germany \\
\hline 27 & Dag M. Hermfelt & Stockholm & Sweden \\
\hline 28 & Ernst J. Huber & Basel & Switzerland \\
\hline 29 & Hermann F. Hummer & Wien & Austria \\
\hline 30 & Henni Ilomäki & Helsinki & Finland \\
\hline 31 & Richard Jeřábek & Brno & Czech \\
\hline 32 & Heinke M. Kalinke & Freiburg im Br. & Germany \\
\hline 33 & Mare Kõiva & Tartu & Estonia \\
\hline 34 & Konrad Köstlin & Wien & Austria \\
\hline 35 & Else Marie Kofod & København & Denmark \\
\hline 36 & $\begin{array}{l}\text { Bronisława Kopczyńska } \\
\text { Jaworska }\end{array}$ & - Łódź & Poland \\
\hline
\end{tabular}




\begin{tabular}{|c|c|c|c|}
\hline No & Name & City & Country \\
\hline 37 & Maria Lioba Lechner & Marburg & Germany \\
\hline 38 & $\begin{array}{l}\text { Constanze Lindner- } \\
\text { Haigis }\end{array}$ & München & Germany \\
\hline 39 & József Liszka & Dunaszerdahely & Hungary \\
\hline 40 & Patricia Lysaght & Dublin & Ireland \\
\hline 41 & Ljiljana Marks & Zagreb & Croatia \\
\hline 42 & Cornelia Maier & Salzburg & Austria \\
\hline 43 & Helga Maier & Salzburg & Austria \\
\hline 44 & Vera Mayer & Wien & Austria \\
\hline 45 & Vacys Milius & Vilnius & Lithuania \\
\hline 46 & Siegfried Neumann & Rostock & Germany \\
\hline 47 & Britt Nordström Sahba & Stockholm & Sweden \\
\hline 48 & Svetla Petkova & Sofia & Bulgaria \\
\hline 49 & Gerhard Prinz & Stuttgart & Germany \\
\hline 50 & Aldis Př telis & Rága & Latvia \\
\hline 51 & Baiba Putnina & Rága & Latvia \\
\hline 52 & $\begin{array}{l}\text { Marina Victorovna } \\
\text { Reily }\end{array}$ & Sankt-Peterburg & Russia \\
\hline 53 & Karin Maria Rooleid & Tallinn & Estonia \\
\hline 54 & Koos Schell & Amsterdam & Netherlands \\
\hline 55 & Herbert Schempf & Korntal & Deutschland \\
\hline 56 & Margot Schindler & Wien & Austria \\
\hline 57 & Thomas K. Schippers & Aix en Provence & France \\
\hline 58 & Gustav Schöck & Stuttgart & Germany \\
\hline 59 & Manfred Seifert & Passau & Germany \\
\hline 60 & Attila Selmeczi Kovács & Budapest & Hungary \\
\hline 61 & Kai Detlev Sievers & Kiel & Germany \\
\hline 62 & $\begin{array}{l}\text { Ann Helene Bolstad } \\
\text { Skjelbred }\end{array}$ & Oslo & Norway \\
\hline 63 & Ülo Valk & Tartu & Estonia \\
\hline 64 & Jeroen Walterus & Brussel & Belgien \\
\hline 65 & Sylvia Wanz & Graz & Austria \\
\hline 66 & Roland Weibezahn & Achim & Germany \\
\hline 67 & Erich Wimmer & Würzburg & Germany \\
\hline 68 & Mechthild Wiswe & Braunschweig & Germany \\
\hline 69 & Nora Witzmann & Wien & Austria \\
\hline 70 & Marianne van Zuijlen & Amsterdam & Netherlands \\
\hline
\end{tabular}




\section{References}

Alsheimer, Rainer 1989. Die Internationale Volkskundliche Bibliographie (IVB) auf dem Wege zu einer Institutionalisierung. Ethnologia Europaea 19, pp. 203-205.

Alsheimer, Rainer 1990. Die Internationale Volkskundliche Bibliographie (IVB): The International Folklore Bibliography (IFB). Zeitschrift für Volkskunde, Vol. 86, No. 2, pp. 244-250.

Alsheimer, Rainer (ed.) 1993. Systematisieren und Thesauri. Sacherschliessung für das Fach Volkskunde/Europäische Ethnologie. Papiere der 3. Tagung der SIEF-Kommission für die Internationale Volkskundliche Bibliographie (IVB) vom 30. April bis 3. Mai 1992 in Rheinfelden (Schweiz). Bremen: Universität Bremen, Studiengang Kulturwissenschaft.

Alsheimer, Rainer 2001. Vorwort. Internationale Volkskundliche Bibliographie für das Jahr 1998. Bonn: Rudolf Habelt, pp. V-VII.

Alsheimer, Rainer \& Doelman, Eveline \& Weibezahn, Roland (eds.) 2000. Wissenschaftlicher Diskurs und elektronische Datenverarbeitung: Bericht über zwei Tagungen der Internationalen Volkskundlichen Bibliographie (IVB) in Amsterdam und Trešt. Volkskunde \& Historische Anthropologie 1. Bremen: Universität Bremen \& Amsterdam: Meertens Instituut.

Beitl, Klaus \& Hummer, Hermann (eds.) 1996. Internationale Volkskundliche Bibliographie: Systematik und Datenbanken:Papiere der 5. Tagung der Arbeitsgruppe für die Internationale Volkskundliche Bibliographie (IVB) vom 8. bis 10. September 1994 in Petronell-Carnuntum (Niederösterreich) und Kittsee (Burgenland). Buchreihe der Österreichischen Zeitschrift für Volkskunde; 13. Wien: Selbstverlag des Vereins für Volkskunde.

Beitl, Klaus \& Kausel, Eva (eds.) 1991. Internationale und nationale volkskundliche Bibliographien: Spiegel der Wissenschaft Volkskundel Europäische Ethnologie: Referate der 2. Tagung der Arbeitsgruppe für die Internationale Volkskundliche Bibliographie (IVB) und zugleich des 4. Internationalen Symposions des Instituts für Gegenwartsvolkskunde der Österreichischen Akademie der Wissenschaften vom 19. bis 21. April 1991 in Neusiedl / See (Burgenland). Buchreihe der Österreichischen Zeitschrift für Volkskunde 9. Wien: Selbstverlag des Vereins für Volkskunde.

Bimmer, Andreas C. 2001/2003. Lesen und Gelesenwerden: Zur Lage gegenwärtigen volkskundlichen Publizierens. Hessische Blätter für Volksund Kulturforschung, No 37/38, pp. 7-11.

Brednich, Rolf Wilhelm 1977/1978. Die Internationale Volkskundliche Bibliographie. Ethnologia Europaea, No. 10, pp. 185-191.

Dow, James R. 1987. Recientes Desarrollos en la International Folklore Bibl iography. Folklore Americano. No. 43, pp. 33-41.

Dow, James R. 1989. The Folklorist as Bibliographer. Camp, Ch. (ed.). Time \& Temperature: A Centennial of the American Folklore Society, pp. 21-22.

Wildhaber, Robert 1966. Die Internationale Volkskundliche Bibliographie. Volkskunde, No. 66, pp. 94-105. 